\title{
SOCIAL NETWORK AND LAND CONFLICT IN RURAL COMMUNITIES (CASE STUDY IN SENAMA NENEK VILAGE TAPUNG HULU SUB REGENCY KAMPAR REGENCY)
}

\author{
MEKI HERLON ${ }^{1)}$, FAJAR RESTUHADI ${ }^{2)}$, ROZA YULIDA ${ }^{2)}$ \\ 1) Masters of Science's alumnus in Universitas Riau \\ ${ }^{2)}$ Masters of Science's lecturer in Universitas Riau \\ email : meki.hr@gmail.com
}

\begin{abstract}
One of the government effort in accelerated development is believed to be done with maximum natural resource management, sustainable, and without any conflict. This 2800 ha of land conflict happened between rural citizen in sub regency Tapung Hulu and PTPN V Kebun Sei Kencana. The aim of this research is to find out information about social network and land conflict in rural communities in Senama Nenek vilage. This research is done within November 2015 until March 2016. Research method is using survey method and research sample for community leaders (12 people by census) and ordinary citizen (113 people by Snow Ball). The data that needed is primary and secondary data, the analysis used SPSS and UciNet program. The result showed that there are 12 actors involved in this conflict which are : 8 actors that maintain customary land (Ishk, Myya, Mkwr, Frds, Abms, Ahyn, dan Tmsn) and 4 actors uphold interests of the company (Abcn, Sprn, Sjls, dan Srdi). The result of network analysis shows that actor which maintain customary land that has importance value and highest strength is Yrmt and actor which uphold interests of the company is Abcn. Seen from the correlation between every actor, actor that has highest strength (OutDeg) and authority (InDegree) in influencing other actors is Yrmt which has 63.63\% score and actor that uphold partially interests of the company is Abcn which has $27.27 \%$ score.
\end{abstract}

Keywords : customary land, conflict, social network and conflict actor

\section{PENDAHULUAN}

\section{Latar Belakang}

Salah satu langkah pemerintah dalam memicu percepatan pembangunan dilakukan dengan pengelolaan sumber daya alam (lahan) secara maksimal dan berkelanjutan. Salah satu desa yang memiliki potensi daerah pengembangan lahan perkebunan adalah Desa Senama Nenek Kecamatan Tapung Hulu Kabupaten Kampar Provinsi Riau (Fajar, R., Kurnia, D., Andriani, Y., Herlon, M., Fauzan, R. 2015).

Pengelolaan sumber daya lahan dapat dilakukan oleh BUMN ataupun swasta. Pemerintah memiliki pemikiran bahwa dengan dilakukannya eksploitasi sumber daya alam akan membuat perekonomian menjadi meningkat, sementara masyarakat berfikir bahwa dengan dilakukan eksploitasi sumber daya alam merupakan suatu penjarahan yang harus dihentikan, pertentangan antara pengelola dan masyarakat inilah yang banyak menimbulkan konflik. Konflik adalah merupakan suatu proses sosial yang berlangsung dengan melibatkan orang atau 
kelompok yang saling menantang dengan ancaman kekerasan (Narwoko dan Suyanto, 2005).

Desa Senama Nenek merupakan desa yang memiliki konflik lahan dengan PT Perkebunan Nusantara V Kebun Sei Kencana. Konflik bermula ketika pertama kali akan dibukanya PT Perkebunan Nusantara V diatas lahan masyarakat dengan melakukan ganti rugi terhadap lahan yang digunakan. Ganti rugi yang dimaksud adalah dengan cara memberikan lahan perkebunan sawit baru tetapi berada di lokasi yang berbeda. Namun, lahan yang diberikan belum juga diberikan hingga menimbulkan konflik antara masyarakat dan PT Perkebunan Nusantara V Kebun Sei Kencana. Penyebaran konflik yang terjadi tidak terlepas dari peran dari tokoh masyarakat atau Ninik Mamak dan elit negeri dengan menggerakkan warga masyarakatnya untuk terlibat dalam konflik.

Perumusan Masalah

Konflik yang terjadi di Desa Senama Nenek adalah konflik antara masyarakat dengan PT Perkebunan Nusantara V Kebun Sei Kencana. Konflik ini tercetus karena adanya ketidakpuasan masyarakat terhadap tindakan PT Perkebunan Nusantara V Kebun Sei Kencana dalam mengelola lahan 2800 ha tanah ulayat Desa Senama Nenek.

\section{Tujuan dan Manfaat}

Adapun tujuan dari penelitian ini adalah untuk:

1. Identifikasi aktor / tokoh masyarakat yang berperan dalam pertikaian atau penyelesaian konflik di Desa Senama Nenek.

2. Analisis peranan jaringan sosial masyarakat (tingkat kepentingan dan kekuatan aktor) dalam mendukung pertikaian atau penyelesaian konflik di Desa Senama Nenek.

Analisis hubungan antar tokoh masyarakat / aktor yang berperan dalam pertikaian atau penyelesaian konflik.

\section{METODE PENELITIAN}

\section{Tempat dan Waktu Penelitian}

Penelitian dilaksanakan di Desa Senama Nenek Kecamatan Tapung Hulu Kabupaten Kampar. Waktu penelitian dilaksanakan mulai bulan Januari-April 2016.

\section{Metode Pengambilan Sampel dan Data}

Metode penelitian yang digunakan adalah metode survey. Sampel yang diambil terdiri dari tokoh masyarakat (12 orang) dilakukan secara sensus dan masyarakat biasa (113 orang) dilakukan dengan metode Snow Ball. Jumlah sampel dalam penelitian adalah 125 responden. Data yang diperlukan adalah data primer dan data skunder.

\section{Metode Analisis Data}

Tujuan penelitian satu digunakan alat analisis deskriptif. Pada tujuan penelitian ke dua alat analisis yang digunakan adalah diagram kartesius (program SPSS). Pada tujuan penelitian ke tiga digunakan alat analisis jaringan sosial (sosmogram), pengolahan dilakukan mengunakan program UciNet. 


\section{HASIL DAN PEMBAHASAN \\ Proses Terjadinya Konflik}

Konflik lahan yang terjadi antara masyarakat Desa Senama Nenek dan PTPN V Sei Kencana sudah lama terjadi. Menurut Wirawan (2010), Konflik yang terjadi dalam masyarakat melalui 7 fase/proses. Proses konflik lahan yang terjadi adalah:

1. Penyebab Konflik : Penyebab konflik antara masyarakat dengan PTPN V Sei kecana adalah kompetisi akan sumber daya yang terbatas (Lahan 2800 ha). Konflik mulai terjadi pada tahun 1989.

2. Fase Laten : Fase laten ini, kedua belah pihak mengakui lahan 2800 ha adalah hak mereka, akan tetapi konflik belum terlihat dikarenakan belum diperlihatkan oleh para aktor/ tokohnya.

3. Fase Pemicu : Fase pemicu awal dimulai pada tahun 2001, Adanya demontrasi yang dilakukan masyarakat terhadap PTPN V Sei Kencana. Tuntutan masyarakat adalah menuntut pihak PTPN V Sei Kencana untuk mengembalikan lahan seluas $2.800 \mathrm{Ha}$ yang dikelola perusahaan kepada masyarakat.

4. Fase Eskalasi : Lembaga lain yang pernah diminta oleh masyarakat untuk membantu dalam penyelesaian masalah adalah: 1). LSM: Lembaga Adat Melayu, Pagar Negeri Bumi Riau (PNBR) Riau, Lembaga penelitian pengkajian dan pengembangan potensi daerah. 2). Pemerintah daerah: Pemerintahan Kabupaten Kampar dan DPRD D Kampar. 3). Pemerintah Propinsi: Pemerintah Propinsi Riau, BPN Riau, Ombusman Riau, DPRD Riau 4). Pemerintah Pusat: Sekretariat Presiden dan Komnas HAM.

5. Fase Krisis : Fase krisis yang terjadi pada tahun 2013, dimana terjadi demonstrasi dan bentrokan antara kedua belah pihak.

6. Fase Resolusi : Kebijakan penggantian lahan seluas 2.800 Ha dengan konsep KKPA masih dianggap sebagai resolusi terbaik dari pemerintah. Dimana lahan penggantian dicari dan sediakan oleh PTPN V (yang baru dapat $93 \mathrm{ha}$ ).

7. Fase Pasca Konflik : Kondisi diwaktu penelitian setelah adanya konflik masih terlihat damai, akan tetapi masyarakat masih belum menerima resolusi konflik yang telah disepakati. Masyarakat masih ada rasa trauma tentang kejadian pada fase kritis.

\section{Identifikasi Aktor / Tokoh Masyarakat yang Terlibat dalam Konflik}

Proses identifikasi perolehan nama aktor yang berperan dalam konflik dimulai dari wawancara dengan aparat desa, masyarakat dan tokoh masyarakat. Dalam penyebutan nama-nama aktor yang terlibat dalam konflik lahan ulayat dilakukan kodesifikasi demi menjaga etika dalam penelitian ini.

\section{Identifikasi, Peran dan Posisi Sosial Aktor}

Secara umum terdapat 12 aktor yang terlibat dalam konflik lahan ulayat masyarakat. Dimana 12 aktor tersebut secara umum terdiri dari 2 kubu yaitu:

\section{Kubu yang Mempertahankan Tanah Ulayat Masyarakat}

Aktor utama yang mempertahankan tanah ulayat masyarakat Desa Senama Nenek berjumlah 8 aktor. Untuk lebih jelas dapat dilihat pada Tabel 1 . 
Tabel 1. Nama aktor yang mempertahankan lahan ulayat Desa Senama Nenek

\begin{tabular}{|c|c|c|c|}
\hline No & Nama Aktor & Posisi Sosial & Peran Dalam Konflik \\
\hline 1 & Ishk & $\begin{array}{l}\text { Tokoh masyarakat/ } \\
\text { Mantan Kades }\end{array}$ & $\begin{array}{l}\text { Tokoh yang memperjuangkan } \\
\text { tanah ulayat melalui } \\
\text { pemerintahannya }\end{array}$ \\
\hline 2 & Мyya & $\begin{array}{l}\text { Nm. Sk Pitopang (DT. } \\
\text { Laksamana) }\end{array}$ & $\begin{array}{l}\text { Pengerak dan pengambil } \\
\text { keputusan dalam suku Pitopang }\end{array}$ \\
\hline 3 & Yrmt & $\begin{array}{l}\text { Nm. Sk Melayu (DT. } \\
\text { Paduko Tuan) }\end{array}$ & $\begin{array}{l}\text { Pengerak dan pengambil } \\
\text { keputusan dalam suku Melayu }\end{array}$ \\
\hline 4 & Mkwr & $\begin{array}{l}\text { Nm. Sk Piliang (DT. } \\
\text { Temenggung) }\end{array}$ & $\begin{array}{l}\text { Pengerak dan pengambil } \\
\text { keputusan dalam suku Piliang }\end{array}$ \\
\hline 5 & Frds & $\begin{array}{l}\text { Nm. Sk Mandailing } \\
\text { (DT. Paduko Rajo) }\end{array}$ & $\begin{array}{lcr}\text { Pengerak } & \text { dan } & \text { pengambil } \\
\text { keputusan } & \text { dalam } & \text { suku } \\
\text { Mandailing } & & \end{array}$ \\
\hline 6 & Abms & $\begin{array}{l}\text { Nm. Sk Domo (DT. } \\
\text { Simaju Lelo) }\end{array}$ & $\begin{array}{l}\text { Pengerak dan pengambil } \\
\text { keputusan dalam suku Domo }\end{array}$ \\
\hline 7 & Ahyn & Ketua Pemuda & $\begin{array}{l}\text { Koordinator aksi demo dari } \\
\text { masyarakat }\end{array}$ \\
\hline 8 & Tmsn & $\begin{array}{l}\text { Ketua LSM PNBR } \\
\text { Sekt LAM Riau }\end{array}$ & $\begin{array}{l}\text { Penyusun strategi } \\
\text { koordinator aksi demo }\end{array}$ \\
\hline
\end{tabular}

Sumber: Data olahan 2016

Tabel 1 memperlihatkan, terdapat 1 aktor yang berasal dari luar desa yang ikut serta membela hak tanah ulayat masyarakat Desa Senama Nenek yaitu Tmsn ketua LSM PNBR (Pagar Negeri Bumi Riau). Keikutsertaan Tmsn yang bertindak sebagai ketua LSM PNBR adalah: 1). Tmsn diminta tolong oleh ninik mamak Desa Senama Nenek secara terlulis untuk membantu perjuangan pengembalian tanah ulayat. 2). Tmsn menilai tindakan yang dilakukan oleh PTPN V Kebun Sei Kencana sudah melanggar hak ulayat tanah masyarakat yang dilindungi oleh UUPA No. 5 Tahun 1960.

2. Kubu aktor yang membela sebagian kepentingan perusahaan PTPN V Kebun Sei Kencana.

Sedangkan aktor utama yang mencoba untuk mengikuti keinginan PTPN V Kebun Sei Kencana terdiri dari 4 aktor. Untuk mengetahui aktor yang dimaksud dapat dilihat pada Tabel 2 berikut.

Tabel 2. Nama-nama aktor yang membela kepentingan PTPN V Kebun Sei Kencana.

\begin{tabular}{|c|c|c|c|c|c|}
\hline No & Nama Aktor & \multicolumn{2}{|c|}{ Posisi Sosial } & \multicolumn{2}{|c|}{ Peran Dalam Konflik } \\
\hline 1 & Abcn & $\begin{array}{l}\text { Kades Ter } \\
\text { Nm. T. Sk F }\end{array}$ & & $\begin{array}{l}\text { Pihak yang mencoba } \\
\text { dengan PTPN V }\end{array}$ & berdamai \\
\hline 2 & Sprn & Nm. T. Sk N & & $\begin{array}{l}\text { Pihak yang mencoba } \\
\text { dengan PTPN V }\end{array}$ & berdamai \\
\hline 3 & Sjls & $\begin{array}{l}\text { Nm. T. } \\
\text { Pitopang }\end{array}$ & $\mathrm{Sk}$ & $\begin{array}{l}\text { Pihak yang mencoba } \\
\text { dengan PTPN V }\end{array}$ & berdamai \\
\hline 4 & Srdi & $\begin{array}{l}\text { Nm. T. } \\
\text { Mandailing }\end{array}$ & $\mathrm{Sk}$ & $\begin{array}{l}\text { Pihak yang mencoba } \\
\text { dengan PTPN V }\end{array}$ & berdamai \\
\hline
\end{tabular}

Sumber: Data olahan 2016 
Tabel 2 memperlihatkan terdapat empat aktor masyarakat yang memebela kepentingan PTPN V. Keempat aktor ini memiliki posisi sosial sebagai Ninik Mamak pada masing-masing suku. Proses pengangkatan ninik mamak ini dilakukan secara sepihak dan tidak memiliki bukti tertulis (SK Bupati Kampar dan Lembaga Adat Kampar). Pembentukan ninik mamak tandingan bertujuan untuk: 1). Memecah suara masyarakat 2). Memecah konsentrasi masyarakat terhadap tuntutan pengembalian tanah ulayat masyarakat yang diambil PTPN V kebun Sei Kencana. 3). Memperlambat dan meredam terjadinya konflik yang meluas.

\section{Hubungan Antar Setiap Aktor}

Keterlibatan setiap aktor dalam konflik lahan Desa Senama Nenek dapat dilihat melalui hubungan keterikan pada setiap aktor yang ada. Untuk mengetahui hubungan pada masing-masing simpul dapat dilihat pada pembahsan berikut:

\section{Simpul aktor yang mempertahankan tanah ulayat masyarakat Desa Senama Nenek}

Simpul aktor yang memiliki kepentingan untuk mempertahankan tanah ulayat masyarakat Desa Senama Nenek terdiri dari aktor yang dari masyarakat sendiri dan aktor dari masyarakat diluar desa. Untuk mengetahui hubungan antar simpul aktor yang mempertahankan tanah ulayat disajikan pada Gambar 1.

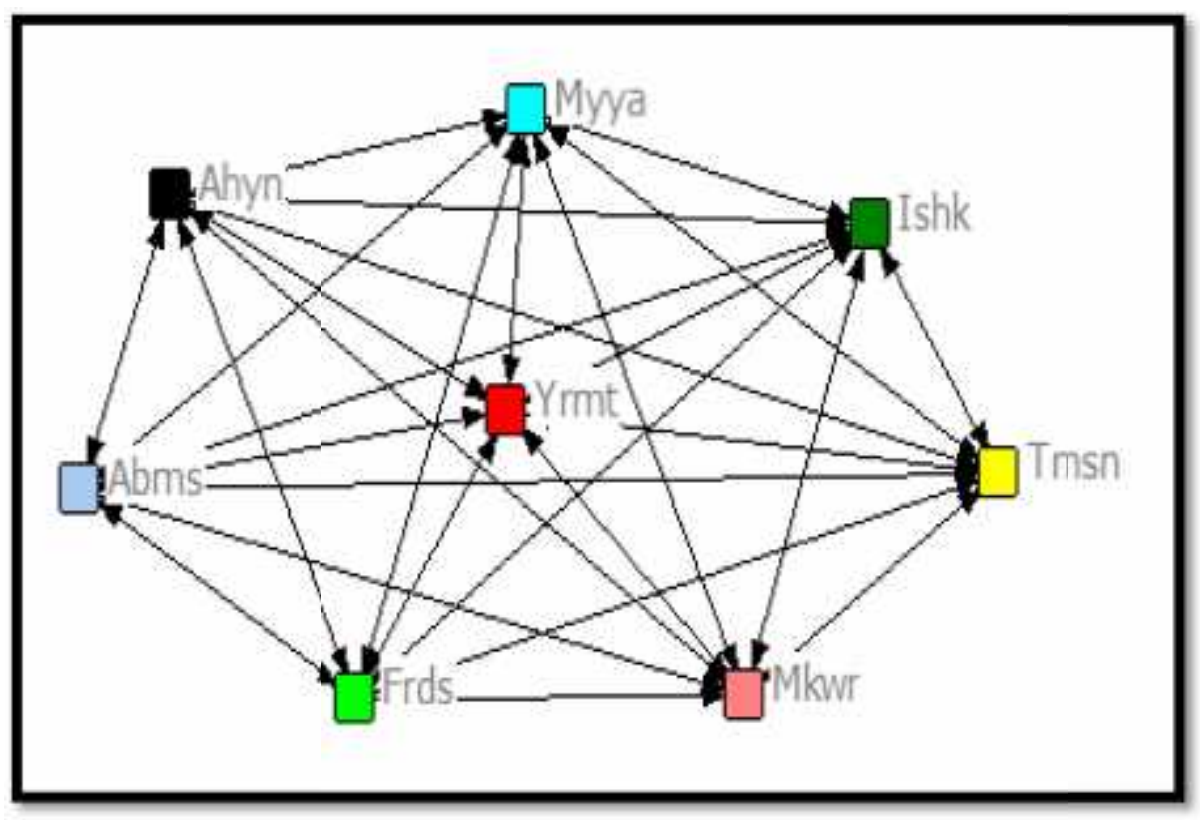

Gambar 1. Hubungan antar aktor yang mempertahankan tanah ulayat

Gambar 1 memperlihatkan bahwa hubungan antar simpul aktor yang tejalin sangat baik. Aktor dalam desa yang memiliki tingkat kekuatan dalam simpul adalah Yrmt, dalam simpul ini juga terbina hubungan antar aktor dalam desa dengan aktor dari luar desa (Tmsn). Aktor yang dari luar desa merupakan salah satu aktifis dari LSM Pagar Negeri Melayu Riau (Ketua) dan Sekretaris Lembaga Adat Melayu Riau.

\section{Simpul aktor yang membela kepentingan PTPN V Sei Kencana}

Dalam konflik lahan yang terjadi terdapat tokoh masyarakat desa yang lebih berfihak kepada perusahaan. Simpul aktor yang berpihak kepada kepentingan perusahaan dapat dilihat pada Gambar 2. 


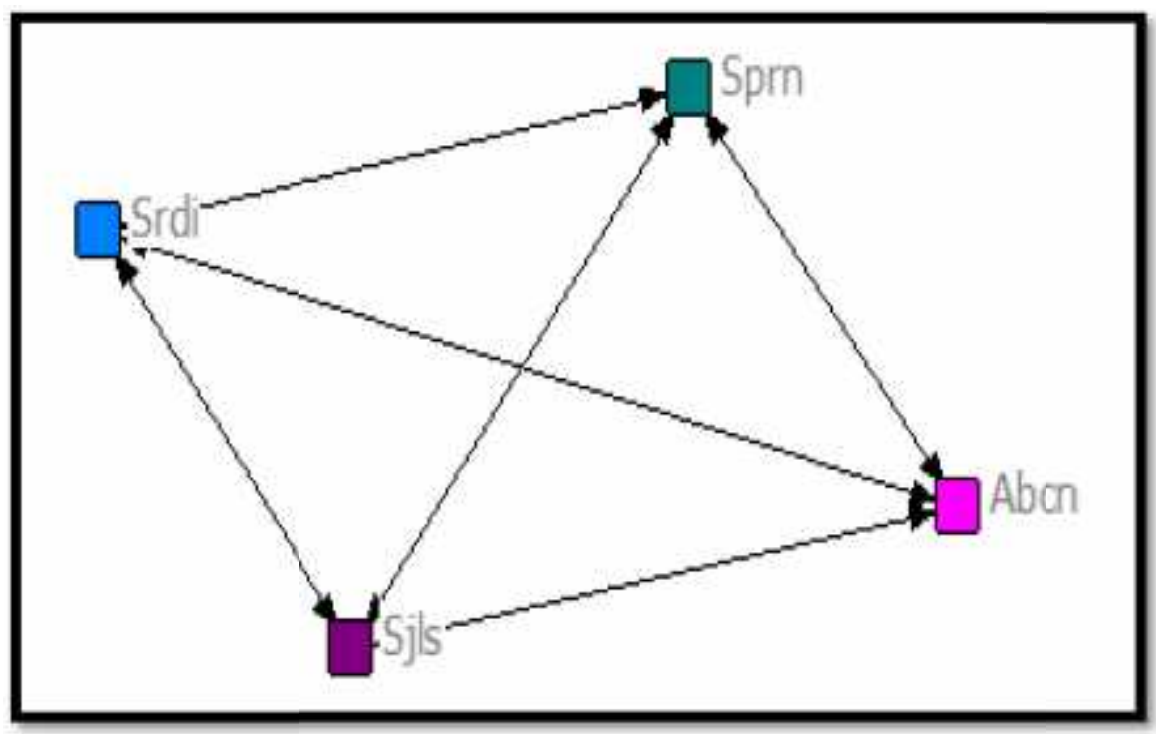

Gambar 2. Hubungan antar aktor yang membela kepentingan PTPN V Sei Kencana

Gambar 2 memperlihatkan bahwa terdapat empat aktor/tokoh masyarakat yang lebih berpihak kepada perusahaan. Keempat aktor ini memiliki kedudukan sosial sebagai ninik mamak tandingan pada suku masing-masing. Selain simpul hubungan antar aktor, seorang aktor diyakini memiliki kekuasan dan kemampuan untuk mempengaruhi aktor lain. Hasil pengolahan data dengan sosmogram memperlihatkan tingkat kekuatan aktor dalam mempengaruhi aktor lain dan kekuasaan aktor dalam jaringan tersebut (Tabel 3).

Tabel 3. Tingkat Kekuatan (OutDeg) dan Kekuasaan (InDegree) aktor

\begin{tabular}{clcc}
\hline No & Nama Aktor & NrmOutDeg & NrmInDeg \\
\hline 1 & Yrmt & 63.636 & 54.545 \\
2 & Myyh & 54.545 & 27.273 \\
3 & Ishk & 45.455 & 36.364 \\
4 & Ahyn & 36.364 & 36.364 \\
5 & Frds & 36.364 & 45.455 \\
6 & Tmsn & 36.364 & 45.455 \\
7 & Mkwr & 27.273 & 27.273 \\
8 & Abcn & 27.273 & 27.273 \\
9 & Abms & 27.273 & 45.455 \\
10 & Srdi & 27.273 & 27.273 \\
11 & Sjls & 18.182 & 18.182 \\
12 & Sprn & 18.182 & 27.273 \\
\hline
\end{tabular}

Network Centralization (Outdegree) $=31.405 \%$

Network Centralization (Indegree) $=21.488 \%$

Tabel 3 memperlihatkan bahwa aktor yang memiliki tingkat kekuatan dan kekuasaan dalam mempengaruhi aktor lain adalah Yrmt dengan tingkat kemampuan mempengaruhi aktor lain sebesar 63.63\%, sehingga Yrmt bertindak sebagai komunikator dan fasilitator dalam sistem. Sedangkan aktor yang membela sebagian kepentingan perusahaan PTPN V Kebun Sei Kencana yang memiliki 
tingkat kemampuan dalam mempengaruhi aktor lain adalah Abcn sebesar 27.27\%. Dilihat dari tingkat sentralisasi jaringan mempengaruhi aktor lain diukur dari sudut Out Degree $31.40 \%$ dan sentralisasi jaringan kekuasaan diukur dari sudut In Degree $21.48 \%$.

\section{Peranan Jaringan Sosial (tingkat kepentingan dan kekuatan aktor) dalam Konflik}

Terdapat dua kubu aktor yang berperan dalam konflik lahan di Desa Senama Nenek. Aktor yang memperjuangkan tanah ulayat (8 orang) dan aktor yang berkerja sama dengan PTPN V Sei Kencana (4 orang). Untuk mengetahui seberapa tingkat kekuatan dan tingkat kepentingan aktor dalam konflik dapat dilihat pada Gambar 3.

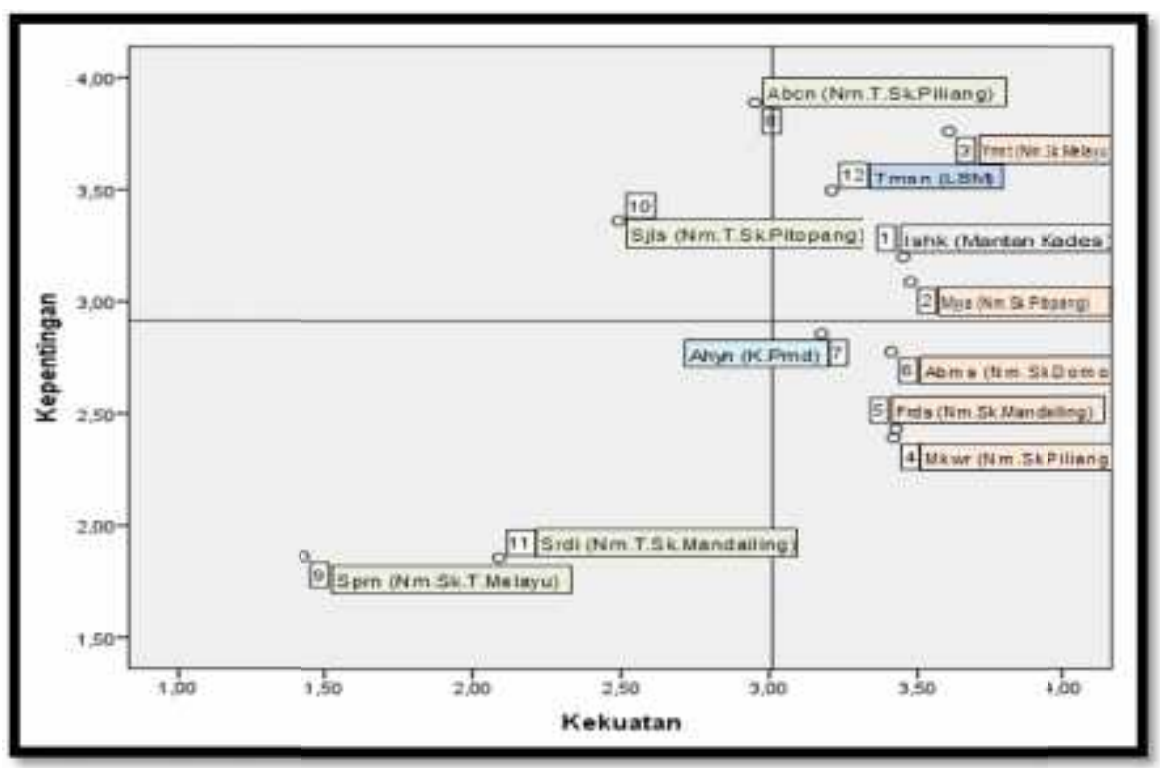

Gambar 3. Tingkat kekuatan dan kepentingan aktor dalam konflik

Gambar 3 memperlihatkan sebaran tingkat kekuatan dan kepentingan dari 12 aktor yang berperan dalam konflik lahan di Desa Senaman Nenek. Untuk lebih jelas dapat dilihat pada pembahasan berikut:

\section{A. Kuadran I}

Terdapat 2 tokoh masyarakat yang berada pada kuadran I. kuadran I merupakan aktor yang memiliki kepentingan diatas nilai rata dan kekuatan dibawah nilai rata-rata. Aktor yang berada di kuadran satu adalah Sjls dan Abcn.

\section{Aktor Sjls}

Aktor Sjls memiliki nilai kepentingan 3.36 dan nilai kekuatan 2.49. Aktor Sjls dianggap masyarakat merupakan aktor yang hanya mementingkan keuntungan sepihak saja dan merupakan aktor kepengikutan aktor Abcn.

\section{Aktor Abcn}

Aktor Abcn memiliki nilai tingkat kepentingan 3.89 dan nilai kekuatan 2.95 hal ini menyatakan bahwa nilai ini dibawah nilai rata-rata. Masyarakat berpendapat bahwa Abcn memiliki kepentingan yang tinggi dalam konflik lahan ulayat dengan alasan:

1. Abcn merupakan masyarakat yang mau bekerjasama dan dipercaya PTPN V

Kebun Sei Kencana dalam mengurangi konflik dengan masyarakat. 
2. Abcn merupakan perpanjangan tangan dari PTPN V Kebun Sei Kencana untuk meredam tuntutan masyarakat terhadap lahan 2800 ha yang telah diambil atau dipergunakan oleh PTPN V Kebun Sei Kencana.

3. Abcn memiliki rasa ketidak puasaan terhadap Mkwr.

4. Abcn mendapatkan bantuan dana untuk menjadi kepala desa dari PTPN V Kebun Sei Kencana.

5. Abcn mendapatkan gaji/pendapatan dari PTPN V Kebun Sei Kencana untuk setiap Bulannya.

6. Abcn merupakan inisiator pembentukan ninik mamak tandingan.

B. Kuadran II

Kuadran II merupakan aktor yang memiliki nilai diatas rata-rata, baik dari kekuatan dan kepentingan. Aktor yang berada pada kuadran II merupakan aktor yang paling potensial dalam penyelesaian masalah konflik. Pada Kuadran II terdapat 4 aktor yang ada yaitu: Yrmt, Tmsn, Ishk dan Myya.

\section{Aktor Yrmt}

Aktor Yrmt memiliki nilai kepentingan 3.76 dan kekuatan 3.60. Nilai kekuatan dan kepentingan aktor Yrmt merupakan nilai tertinggi pada kuadran II. Beberapa pertimbangan masyarakat yang menyatakan bahwa Yrmt memiliki kekuatan dan kepentingan yang tinggi adalah:

1. Secara strata sosial Yrmt merupakan ninik mamak suku melayu, suku melayu merupakan suku tertua di Desa Senama Nenek.

2. Yrmt merupakan pimpinan ninik mamak lima suku Desa Senama Nenek.

3. Yrmt merupakan orang yang dituakan dan dihormati oleh masyarakat.

4. Yrmt merupakan orang yang memiki pengaruh sangat kuat, setiap perkataan Yrmt, masyarakat akan mendengarkan dan mengikutinya.

5. Yrmt tidak suka hak tanah ulayat masyarakat yang diwariskan oleh nenek moyang untuk kesejahteraan masyarakat direbut oleh PTPN V Kebun Sei Kencana.

6. Yrmt menganggap bahwa dengan adanya tanah ulayat desa maka akan memberikan penghidupan bagi anak cucu atau tanah ulayat yang ada dapat dimanfaatkan untuk keberlangsungan hidup anak cucu.

7. Yrmt menganggap bahwa dengan adanya tanah ulayat dapat menjadi tempat tinggal, tempat jika ada masyarakat yang meninggal dunia dikuburkan.

\section{Aktor Tmsn}

Aktor Tmsn memeiliki nilai kepentingan sebesar 3.50 dan kekuatan sebesar 3.21. Beberapa alasan masyarakat menilai aktor ini masuk dalam kuadran II adalah:

1. Tmsn adalah ketua LSM PBNR dan Sekretaris Lam Riau.

2. Tmsn adalah orang Luar Desa Senama Nenek yang mau berkorban membantu masyarakat untuk memperjuangkan hak tanah ulayat masyarakat.

3. Tmsn ikut serta dalam proses pengaturan strategi dalam aksi demo pada fase kritis.

4. Tmsn ikut berperan aktif (memimpin) dalam aksi demo pada fase kritis.

\section{Aktor Ishk}

Secara strata sosial aktor Ishk merupakan tokoh masyarakat dan mantan kepala desa. Aktor Ishk memiliki nilai kepentingan 3.20 dan kekuatan 3.45. Aktor Ishk dinilai masyarkat sebagai aktor yang dari dahulu berusaha untuk 
memperjuangkan hak atas tanah ulayat desa melalui negosiasi melalui jabatan sebagai kepala desa ke perintah daerah dan pemerintah propinsi.

\section{Aktor Myya}

Aktor Myya memiliki nilai kepentingan 3.09 dan kekuatan 3.48. Alasan masyarakat menilai aktor Myya masuk dalam kuadran II disebabkan karena: 1). Myya Ninik mamak yang berusaha memperjuangkan hak atas lahan masyarakat. 2). Myya memiliki jiwa sosial yang mentingkan kepentingan bersama.

\section{Kuadran III}

Terdapat empat 4 aktor yang berada pada kuadran III. Dimana dalam kuadran III memiliki nilai diatas nilai rata-rata kekuatan dan memiliki nilai dibawah nilai rata-rata kepentingan. Empat aktor yang terlibat adalah: Frds, Abms, Mkwr dan Ahyn. Keempat aktor ini merupakan tokoh masyarakat yang memiliki kekuatan untuk mendorong masyarakat mau ikut serta memperjuangkan hak tanah ulayat. Berikut alasan masyarakat menilai aktor yang berada pada kuadaran III.

\section{Aktor Frds}

Aktor Frds memiliki nilai kepentingan 2.43 dan kekuatan 3.34. Beberapa alasan masyarakat menilai Frds sehingga masuk dalam kuadran III:

1) Frds merupakan tokoh masyarakat yang memperjuangkan tanah ulayat.

2) Frds merupakan tokoh panutan masyarakat suku mandailing.

3) Frds pandai menjalin komunikasi dengan masyarakat Desa Senama Nenek.

4) Frds merupakan orang yang tidak membedakan orang berdasarkan kekayaan.

\section{Aktor Abms}

Aktor Abms memiliki nilai kepentingan 2.78 dan kekuatan 3.41. Beberapa pertimbangan Abms dinilai pantas masuk dalam kuadran III adalah:

1) Abms merupakan pimpinan suku yang pandai menjaga persatuan suku domo, hal ini terlihat tidak adanya ninik mamak tandingan suku domo.

2) Abms merupakan tokoh masyarakat yang memiliki kekayaan

3) Abms berupaya untuk memperjuangkan hak dari masyarakat untuk mendapatkan tanah ulaya.

4) Abms merupak pimpinan yang pandai dalam menyikapi setiap permasalahan di dalam suku domo dan cepat untuk menyelesaikannya.

\section{Aktor Mkwr}

Aktor Mkwr memiliki nilai tingkat kepentingan 2.39 dan nilai kekuatan

3.42. Beberapa alasan masyarakat Mkwr dinilai sesuai pada kuadran III adalah:

1) Tanah ulayat yang dikuasai PTPN V Sei Kencana merupakan hak dari masyarakat Desa Senama Nenek yang harus diperjuangkan untuk generasi penerus.

2) Mkwr merupakan orang yang memiliki pola pikir yang baik dan kukuh dalam bersikap.

\section{Aktor Ahyn}

Aktor Ahyn memiliki nilai kepentingan 2.86 dan kekuatan 3.18. Beberapa alasan masyarakat menilai Ahyn masuk dalam kuadran III adalah

1) Aktor yang aktif dalam kegiatan-kegiatan yang dilaksanakan di desa.

2) Aktor yang berada pada garis depan pada saat aksi demo pada fase kritis.

3) Aktor yang bisa menggerakakan tokoh-tokoh pemuda di Desa Senaman Nenek. 


\section{Kuadran IV}

Aktor yang memiliki nilai kekuatan dan kepentingan dibawah nilai ratarata berada pada kuadran IV, yaitu: Sprn dan aktor Srdi. Aktor Sprn (nilai kepentingan 1.86 dan kekuatan 1.43), Srdi (nilai kepentingan 1.86 dan kekuatan 2.09). Kedua aktor ini adalah aktor yang memiliki rasa ketidak puasan terhadap ninik mamak pada suku masing-masing. Akibat ketidak puasan terhadap sikap ninik mamak aktor ini bergabung dengan Abcn.

\section{Upaya yang dilakukan Kedua belah pihak yang bertikai}

\section{A. Upaya Masyarakat dalam Menyelesaikan Konflik Lahan}

\section{Gugatan KUD Bina Mandiri terhadap PTPN V (29 Desember 2010)}

KUD Bina Mandiri yang mewakili 1400 orang warga Senama Nenek melalukan gugatan kepada PTPN V atas hak tanah ulayat seluas 2800 ha yang di kuasai oleh PTPN V ke Pengadilan Negeri Bangkinang. Hasil dari gugatan yang diajukan oleh KUD Bina Mandiri pada tanggal 29 Desember 2010 majelis hakim Pengadilan Negeri Bangkinang menyatakan gugatan KUD Bina Mandiri selaku penggugat tidak dapat diterima.

\section{Gugatan ke Pengadilan Negeri Bangkinang (Tahun 2011)}

Tahun 2011 masyarakat mencoba melakukan gugatan ke PTPN V melalui Pengadilan Negeri Bangkinang. Jumlah gugatan yang coba diajukan oleh masyarakat Desa Senama Nenek berjumlah 2 (dua) gugatan. Pada proses berjalannya persidangan masyarakat mencabut gugatan terhadap PTPN V. Alasan masyarakat mencabut gugatan adalah kurangnya bukti tertulis yang dimiliki oleh masyarakat, sehingga pandangan masyarakat jika kasus ini diteruskan maka masyarakat akan kalah.

\section{Aksi pendudukan paksa oleh masyarakat Desa Senama Nenek (Juli 2012)}

Upaya yang dilakukan masyarakat adalah dengan pendudukan paksa terhadap daerah konflik. Upaya pendudukan paksa ini dilakukan selama 4 (empat) bulan di mulai pada bulan Juli sampai dengan bulan Oktober 2012. Selama masa pendudukan paksa mengakibatkan PTPN V Kebun Sei Kencana mengalami kerugian produksi.

\section{Aksi Demo (21 Oktober 2013)}

Aksi demo tanggal 21 oktober 2013 merupakan aksi puncak dari upaya perjuangan masyarakat senanama nenek untuk memperjuangkan tanah ulayat milik masyarakat senama nenek. Adapun aksi unjuk rasa atau demonstrasi tersebut dilakukan dengan maksud untuk memperjuangkan hak mereka, karena berdasarkan keterangan dari Ninik Mamak Senama Nenek bahwa lahan seluas kurang lebih 2.800 Ha yang saat ini sedang.dikuasai dan dikelola oleh PTPN V adalah lahan/tanah ulayat kenegerian Senama Nenek. Dampak dari aksi demo tersebut adalah 38 orang ditahan polisi dan dua orang karyawan PTPN V mengalami luka-luka, Poltal, atap pos penjagaan security, plang pengumuman tentang pemberitahuan izin lahan PTPN V mengalami kerusakan.

\section{Melakukan Aksi Demo (11 September 2014)}

\section{Upaya Masyarakat dalam Menyuarakan Pendapat}

Masyarakat Desa Senama Nenek dibantu organisasi HMI MPO Pekanbaru, IPMK Pekanbaru dan Hippemark dengan mengatasnamakan sebagai Aliansi Masyarakat Pejuang Sinama Nenek menggelar aksi demo. Aliansi menyuarakan perampasan dan penguasaan 2.800 ha tanah ulayat masyarakat Desa Senama nenek yang dilakukan secara ilegal PTPN V karena tidak ada izin Hak 
Guna Usaha (HGU). Masyarakat menyatakan bahwa keputusan Gubernur Riau pada tahun 2007 PTPN V sudah berjanji akan mengembalikan lahan 2800 ha yang dikuasi, akan tetapi sampai sekarang, lahan tersebut masih dikuasai dan PTPN. Keputusan diperkuat pada tanggal 21 Juli 2014 sudah ada persetujuan dari tim gubenur untuk mengembalikan lahan 2800 ha.

2. Jawaban PTPN V terhadap aksi demo yang dilakukan oleh Aliansi Masyarakat Pejuang Senama Nenek

PTPN V menyatakan bahwa penguasaan lahan sudah melalui prosedur yang berlaku. "Perolehan lahan seluas 2.800 hektar di Kebun Sei Kencana Desa Senama Nenek, Kecamatan Tapung Hulu Kampar, dikuasi perusahaan berdasarkan beberapa izin prinsip, antara lain:

1. SK Menteri Pertanian Nomor 178/KPTS/UM/III/1979 Tahun 1979 tentang Daerah Pengembangan P.N/P.T Perkebunan,

2. SK Gubernur Riau Nomor Kpts.131/V/1083 tahun 1983 tentang Pencadangan Tanah untuk Perkebunan Kelapa Sawit dan Karet seluas 30.000 hektar di Kecamatan Tandun dan Siak Hulu Kabupaten Kampar yang dikelola oleh PT Perkebunan II Tanjung Morawa.

3. SK Menteri Kehutanan Nomor 403/KPTS-II/1996 tentang Pelepasan Hutan Seluas 32.235 hektar di Kelompok Hutan Sei Lindai, Tapung Kiri Kabupaten.

Mengenai SK Gubernur Nomor kpts/470/XII/2007 yang diubah dengan KPTS. 1142/IV/2008 PTPN V sudah mengindahkan isinya dan merekomendasikan lahan tersebut diserahkan kepada masyarakat, dengan mengirimkan surat ke Kementrian BUMN selaku pemegang saham. Hasil rapat dari pemegang saham beserta Komisi VI DPR RI tidak dapat memenuhi rekomendasi demi menjaga kepastian hukum dan perlindungan atas asset PTPN V dan penyelesaian direkomendasikan melaui hukum.

B. Upaya dalam penyelesaian konflik lahan yang dilakukan PTPN V Kebun Sei Kencana

Tahapan dan upaya yang dilakukan oleh PTPN V Kebun Sei Kencana dalam menyelesain konflik lahan ini adalah:

\section{Pembagian sembako}

Langkah pemberian sembako ini ditawarkan oleh PTPN V Kebun Sei Kencana kepada masyarakat Desa Senama Nenek dimana masyarakat akan menerima sembako setiap bulannya selama tanah ulayat masyarakat masih digunakan oleh PTPN V Kebun Sei Kencana, akan tetapi tawaran ini di tolak oleh masyarakat Desa Senama Nenek.

\section{Bagi hasil $(\mathbf{7 0 \%}: 30 \%)$}

Upaya kedua yang dilakukan oleh PTPN V Kebun Sei Kencana untuk meredakan konflik lahan yang terjadi adalah dengan membuat kesepakatan antara PTPN V Sei Kencana dengan masyarakat yang diwakilkan oleh ninik mamak 5 suku, dimana hasil kesepakatan adalah adanya pembagian pendapatan dari lahan yang disengketakan, $30 \%$ untuk masyarakat dan $70 \%$ untuk perusahaan. Hasil kesepatan ini hanya berjalan selama 6 bulan, pihak PTPN V Kebun Sei Kencana memutuskan kesepakatan ini, dengan alasan bahwa perusahaan mengalami kerugian jika menjalankan pola ini.

\section{Pemberian uang ganti sebesar 20 Milyar untuk 5 Ninik Mamak}

Salah satu langkah yang dilakukan oleh PTPN V Kebun Sei Kencana untuk meredakan konflik adalah dengan memberikan uang sebesar 20 milyar 
untuk 5 orang ninik mamak, dengan kesepakatan masalah konflik lahan ini tidak dipermasalahkan oleh masyarakat, tapi tawaran ini ditolak oleh ninik mamak. Penolakan ini berdasarkan pertimbangan: 1). Tanggung jawab ke anak dan kemanakan pada masing-masing suku, 2). Tidak semua orang bisa diukur dengan uang, 3). Jika uang Rp. 20 milyar dianggap sebagai uang ganti rugi lahan 2800 ha, jumlah ini tidak seimbang ( 84 milyar).

\section{Pembentukan ninik mamak tandingan}

Langkah manajemen konflik yang dilakukan adalah pembentuk ninik mamak tandingan untuk masing-masing suku. Upaya pembentukan ninik mamak tandingan ini berhasil pada suku piliang (Abcn), suku melayu (Sprn), Suku Pitopang (Sjls) dan suku mandailing (Srdi), sedangkan untuk suku domo tidak bisa berjalan dengan baik hal ini disebabkan karena suku domo lebih kompak. Tujuan pembentukan dari ninik mamak tandingan adalah untuk memecah belah masyarakat dari dalam, sehingga konsentrasi masyarakat terhadap tututan kepada PTPN V Sei Kencana tidak berjalan mulus.

\section{Take over lahan (secara bertahap)}

Usaha pembentukan ninik mamak tandingan yang dibentuk PTPN V Sei Kencana berbuah hasil yang cukup baik bagi PTPN V Sei Kencana, hasil yang diperoleh adalah adanya kesepakatan bahwa masyarakat tidak menuntut lahan 2800 ha untuk dikembalikan kepada masyarakat akan tetapi PTPN V menganti lahan 2800 ha pada daerah lain. Proses terbentuk kesepakatan dimediasi oleh DPD, Ombudsman, Komnas HAM dan Pemda. Hasil pertemuannya adalah terjadi kesepakat untuk menyelesaikan sengketa dengan cara take over lahan dengan skim KKPA.

\section{KESIMPULAN} bahwa:

Berdasarkan hasil dari penelitian ini maka dapat ditarik kesimpulan

1. Dalam konflik ini terdapat 12 aktor yang terlibat dalam konflik ini yaitu: 8 aktor yang mempertahankan tanah ulayat dan 4 aktor membela kepentingan perusahaan.

2. Aktor yang mempertahankan tanah ulayat yang memiliki nilai kepentingan dan kekuatan tertinggi adalah Yrmt (Nm. Sk. Melayu) dan aktor yang membela kepentingan perusahaan adalah Abcn (Nm. T. Sk. Piliang).

Dalam hubungan antar setiap aktor, aktor yang memiliki tingkat kekuatan (OutDeg) dan kekuasaan (InDegree) dalam mempengaruhi aktor lain adalah Yrmt dengan tingkat kemampuan mempengaruhi aktor lain sebesar $63.63 \%$, sedangkan pada aktor yang membela sebagian kepentingan PTPN V adalah Abcn sebesar $27.27 \%$.

\section{DAFTAR PUSTAKA}

Fajar, R., Kurnia, D., Andriani, Y., Herlon, M., Fauzan, R. 2015. Pengkinian Data Pemetaan Sosial (Social Mapping) Daerah Sekitar Wilayah Kerja Badan Operasional Bersama PT. Bumi Siak Pusako - Pertamina Hulu. Technical Report. Cv. Kurnia Tandan Mas. Siak Sri Indrapura, Riau.

Narwoko J. Dwi dan Suyanto Bagong. 2005. Sosiologi Teks Pengantar dan Terapan. Kencana Prenada Media Group. Jakarta.

Wirawan. 2010. Konflik dan Manajemen Konflik, Teori Aplikasi dan Penelitian. Salemba Humanika. Jakarta. 